\title{
УДК 902 \\ EXPERIMENTAL STUDIES ON ERTEBØLLE POTTERY: FOOD PREPARATION AND RADIOCARBON DATING
}

\author{
(C) 2015 \\ Бенте Филиппсен, доктор, Орхусский центр АМС, Факультет физики и астрономии \\ Орхусский университет, Архус (Дания)
}

\begin{abstract}
Аннотация. В статье подводятся итоги археологического экспериментального исследования о наиболее раннем типе керамики на территории Северной Германии и Дании, которая принадлежит культуре рыболововсобирателей позднего мезолита - Эртебёлле. В работе описаны эксперименты приготовления пищи и обжига сосудов, представляющих собой копии посуды Эртебёлле. Автор объясняет, как сбор данных с экспериментов по нагару может помочь при поиске ответов на вопросы, возникающие при радиоуглеродном резервуарном эффекте и измерение стабильных изотопов по нагару. В статье анализируется, как приготовление морской или пресноводной рыбы для употребления в качестве пищи приводит к появлению резервуарного периода в керамике. Результаты экспериментов будут сравнивать с другими материалами из культурного слоя. В работе объясняется значение данных экспериментальных исследований для радиоуглеродного датирования сосудов, а также для изучения назначения керамики и ее характеристик.
\end{abstract}

Ключевые слова: Радиоуглеродное датирование, мезолит, керамика, культура Эртебёлле, анализ стабильных изотопов, нагар.

\section{Introduction}

Pottery is one of the most important materials in archaeological research. Pottery was an every-day product, produced in great amounts and for various purposes, from storage over food preparation to burial and rituals. The shape and appearance of the pottery is only to a little degree determined by functional constraints, so cultural developments can be expressed in the ceramics. As Hayashida [1] remarks, "There may be many ways to make a sturdy cooking pot given available materials but the particular clays chosen and the techniques used to form, finish, and fire the vessels are linked to such diverse factors as the organization of the potters, their social identity, the perception of different raw materials and fuels, and the integration of pottery-making with other activities". This variability makes it possible to establish methods of typological dating, assuming that different pieces of pottery, looking the same and made and decorated in the same way, are contemporaneous. Another assumption is that changes only occur gradually, so that it is possible to build up a so-called "typological sequence". Apparently, people in certain cultures and in certain times all used the same techniques and shapes for producing pottery, although many different kinds of pottery would serve the same purpose.

However, for linking the relative dates of the typological sequences to the calendar time scale, we need to date the pottery with scientific methods. Radiocarbon dating is a well-established method for absolute age determination, but may be problematic in the case of pottery: often associated finds are dated, which can give incorrect ages in case of redeposition of finds or unclear stratigraphy. Direct radiocarbon dating of the pottery avoids those problems. Radiocarbon dating of individual sherds became possible with the introduction of accelerator mass spectrometry, AMS [2]. However, the large variety of datable materials in and on the pottery necessitates a thorough methodological approach [3]. Soot in and on the clay matrix can introduce an old wood effect; plant remains, which are classified as temper, might originate from the clay pit and thus be much older than the date of pottery production [4]; carboncontaining compounds can enter the pottery during burial; and, finally, charred food remains on the sherds and absorbed lipids can originate from food resources introducing reservoir effects.

This article focuses on the problem of radiocarbon reservoir effects in pottery dating. Plants and animals from the sea, lakes and rivers can have radiocarbon ages which are hundreds to thousands of years older than the "true age" of these samples. In case those resources were prepared in the pottery, their reservoir effect is transferred to the food residues on the sherds [5]. Experiments were needed to proof that a reservoir effect is transferred from the ingredients to the food crusts, and to build a reference collection of food crust samples with known ingredients, in order to test stable isotope analysis and other methods for the reconstruction of ingredients. Many of the results presented here have been published before, e.g. in my $\mathrm{PhD}$ thesis [6] and in several articles [7-10].

\section{Research History}

Ertebølle pottery sherds can appear thick, fragile and porous when excavated. Therefore, early research doubted the suitability of the pots for food preparation. Klinge [11], Klinge [12] for example tried to boil water in rebuilt Ertebølle pots, but he did not succeed because the water was evaporating through the pores of the pot already at $70-90^{\circ} \mathrm{C}$. Therefore, he concluded that the pots were only used as salterns for sea water. Ertebølle pots that were found in the inland, far away from supplies of sea water, contradicted this interpretation [13]. Later, finds of food crusts on Ertebølle sherds provided the knowledge that the examined type of pottery was used 
for the processing of food and not, for example, only for carrying or storing water [14]. Later experiments in which starch or fat had been added to the liquid in the pot also disagree with Klinge's conclusion that the pots were unsuitable for boiling food: the pores of the pot were sealed with starch or fat so that the content could be heated up to the boiling point (Andersen and Malmros 1984). In contrast to that, a charred crust on the inside of a pot can have a completely different reason, as ethnographical observations indicate: In Western Sudan, simple clay pots have been waterproofed by filling them with grass or stray before firing them upside down. The soot layer in the pots prevented water from soaking through the pores and thus waterproofed the pottery [15]. However, as our experiments showed, it is neither necessary to add starch or fat nor to waterproof with soot, when boiling water in Ertebølle pottery (see below).

A possible freshwater reservoir effect on pottery was indicated by Fischer and Heinemeier [16] in a study on Stone Age sites in the Åmosen bog, Denmark. Pottery dating from Estonia has in one case given a date that was 1000 years older than expected [17]. This dating may be correct and the archaeological assumption may have to be corrected, but it is also possible that the hardwater effect contributed to the high age of the pottery which was found on a site at a river bank [17]. Nakamura, Taniguchi [18] report ages as high as $15,710-16,540 \mathrm{cal}$ BC for the earliest Japanese pottery. It had been assumed before that the use of pottery started with the Jomon Culture in the Holocene after a series of climatic fluctuations. The AMS dating of pottery, though, suggest that the first pottery was already made during a cold climate period "predating such climatic fluctuations by about a millennium". It would be interesting to examine this pottery closer to find out if it also had been influenced by the hardwater effect or if those surprisingly high radiocarbon ages also correspond to high historical ages. Up to now, the younger ages of charcoal samples have been explained with the assumption that these charcoal pieces really are younger and have been anthropogenically or naturally mixed into the layers in which the pottery was found [18].

\section{Objective and Methods}

The objective of this study is to examine Ertebølle pottery as cooking vessels - both their suitability for food preparation, the risk of reservoir effects and the adequacy of stable isotope measurements $(\delta 13 \mathrm{C}, \delta 15 \mathrm{~N})$ for detecting aquatic ingredients.

Copies of the typical pointed-base vessels of the Ertebølle culture were formed and fired in an open fire [19]. Afterwards, they were used to prepare different ingredients and mixtures of ingredients. The food was left to char in the pots, and samples were collected of fresh, cooked, and charred food.

Food crust samples were pre-treated in the same way as archaeological food crust samples, to ensure comparability. Furthermore, both pre-treated and not pretreated samples were analysed to explore the influence of the chemical pretreatment methods on a food crust's stable isotope values. Details about the procedures and measurements can be found in Philippsen [6].

\section{Results}

The pottery was formed from coils, which were placed upon the pointed base and smoothed [19]. The pottery was fired in an open fire, made on pre-heated ground. The fire was moved closer to the pots and enlarged in a very slow and controlled process. However, some of the pots cracked during firing. This was especially the case for pots that hadn't dried sufficiently - an adequate drying time is several weeks for the thick-walled Ertebølle pottery. The way in which the vessels cracked agrees with archaeological finds of Ertebølle pottery sherds [20]. For example, some pointed bases blasted off during firing (certainly because the clay had its greatest thickness in that part of the vessel and hadn't dried sufficiently), and a pot cracked along a coil. Cracks all over the surface of the pottery, which previously had been ascribed the thermal shock during cooking [21], proved to be the result of the firing. They were especially found close to coarse temper grains [19].

After firing, the hand-formed pottery was hard and almost waterproof. It was possible to get pure water boiling by placing a water-filled pointed base vessel on a small cooking fire. Thus, Klinge's [11, 12] assumption that Ertebølle pottery was not suitable for boiling was falsified as well as Andersen and Malmros' [14] assumption that fat or starch was needed to seal the pores, in order to heat the food to the boiling point.

Handling the pots on different kinds of fireplaces gave interesting information about the shape of the pottery - some elements, which might have been regarded as purely stylistical, proved to enhance the practicality of the pottery. The solid pointed base made the pots stand stable on different kinds of fireplace, e.g. on three stones above a cooking fire, or in the embers at the edge of a larger campfire. The everted rim and S-shaped profile of the vessels makes it easy to handle them - they can be taken off from the fire using two sticks, so the pottery can be moved even though it is still hot.

The cooking vessels experienced different varieties of thermal shock, such as large temperature differences on opposite sites, or as cold liquids poured into hot pots. However, no vessel cracked during the cooking experiments. Boiling and charring food even sealed one of the pots, which had cracked along the coils during firing. The thermal shock resistance might be the result of the temper material, relatively large amounts of crushed granite [19].

As we cooked different mixtures of ingredients in the vessels, it became clear that charred food crusts do not form during normal food preparation, i.e., during boiling until the food is cooked. We had to wait for up to several hours, before the entire water was boiled away and the formation of a crust began. Starch-rich ingredients facilitated crust formation, as well as very 
fatty ingredients. The high numbers of food crusts at some sites may therefore suggest the preparation of starchy and/or fatty ingredients in the pottery.

Stable isotope measurements revealed only small changes in isotope values during cooking and charring. Therefore, stable isotope values of a food crust can be used to indicate the stable isotope values of the original ingredients. However, in mixtures of different food stuffs with different isotope values, very different isotope values can be measured on food crust samples collected from different parts of the vessel. Pieces of the different ingredients adhere to, and char at, different spots within the cooking container. Therefore, the measurement of a single food crust sample might not be representative for the food prepared in that container - or for the food generally prepared at the site. Multiple measurements are therefore necessary. In addition to providing good statistics for diet reconstruction, great numbers of food crust analyses will display the variability in food resources. Furthermore, some conclusions about the nature of the cooked food can be drawn: highly variable isotope values from the same vessel indicate that pieces or lumps of different ingredients were cooked. Uniform isotope values within one pot indicate cooking of only a single foodstuff, or of a thoroughly homogenized mixture of ingredients.

\section{Conclusions and outlook}

Experiments can reveal that some of the stylistic characteristics of a certain pottery style are governed by functionality. Pottery experiments can reveal what is possible - and what not - when forming and utilizing ceramic containers. For example, we found that thickwalled pointed-base pottery requires long periods for drying. Therefore, pottery production seems to require some degree of sedentariness. Not because the finished ceramics are difficult to transport - they are quite sturdy - but because of the long periods of drying before firing. People need to have available, dry space for storing the pottery several weeks before firing.

Marine and freshwater reservoir effects are of concern when radiocarbon dating pottery. Stable isotope values of food crusts can indicate the presence of aquatic ingredients. However, due to the large variability in especially the freshwater reservoir effect, and the potentially small isotopic differences between freshwater and terrestrial ingredients, it is impossible to quantify the expected freshwater reservoir effect in a food crust based on isotope measurements. Instead, stable isotope measurements should be used to identify the presence of aquatic ingredients, and to choose terrestrial food crusts for dating.

We have buried sherds with food crusts, and excavated them again after one year in the ground. Their isotope values will be compared to values of non-buried experimental crusts and thus indicate how large isotopic changes due to degradation in the burial environment we can expect.

\section{LIST OF REFERENCES}

1. Hayashida, F., Bridging the Gap between Archaeology and the Physical Sciences. Hyperfine Interactions, 2003. 150: p. 7-11.

2. Johnson, R.A., et al., Archaeologic sherd dating: Comparison of thermoluminescence dates with radiocarbon dates by beta counting and accelerator techniques. Radiocarbon, 1986. 28(2A): p. 719-725.

3. de Atley, S.P., Radiocarbon dating of ceramic materials: progress and prospects. Radiocarbon, 1980. 22(3): p. 987-993.

4. Hedges, R.E.M., C. Tiemei, and R.A. Housley, Results and methods in the radiocarbon dating of pottery. Radiocarbon, 1992. 34(3): p. 906-915.

5. Philippsen, B., Hard Water or High Ages? 14C food crust analysis on Mesolithic pottery from Northern Germany, Master thesis at Department of Physics and Astronomy, Aarhus University and Institut für Umweltphysik, Universität Heidelberg.2008.

6. Philippsen, B., Variability of freshwater reservoir effects: Implications for radiocarbon dating of prehistoric pottery and organisms from estuarine environments, $\mathrm{PhD}$ thesis at AMS 14C Dating Centre, Department of Physics and Astronomy 2012, Aarhus University.

7. Philippsen, B., Terminal Mesolithic Diet and Radiocarbon Dating at Inland Sites in SchleswigHolstein, in Landscapes and Human Development: The Contribution of European Archaeology. Proceedings of the International Workshop «Socio-Environmental Dynamics over the Last 12,000 Years: The Creation of Landscapes (1st - 4th April 2009)», Kiel Graduate School «Human Development in Landscapes». 2010, Dr. Rudolf Habelt GmbH: Bonn. P. 21-36.

8. Philippsen, B., Der Süßwasser-Reservoireffekt in der 14C-Datierung: neue Analysen und mesolithische Kochexperimente. Experimentelle Archäologie in Europa - Bilanz, 2013. 2013: p. 20-32.

9. Philippsen, B., A. Glykou, and H. Paulsen, Kochversuche mit spitzbodigen Gefäßen der Ertebøllekultur und der Hartwassereffekt, in Experimentelle Archäologie in Europa - Bilanz, U. Weller, et al., Editors. 2012, Europäische Vereinigung zur Förderung der Experimentellen Archäologie / European Association for the advancement of archaeology by experiment e.V.: Unteruhldingen. P. 33-48.

10. Philippsen, B., et al., The hardwater effect in AMS 14C dating of food crusts on pottery. Nuclear Instruments and Methods in Physics Research Section B: Beam Interactions with Materials and Atoms, 2010. 268(7-8): p. 995-998.

11. Klinge, M., De store Lerkar i Stenalderens Affaldsdynger. Naturens verden, 1932. 16(1): p. 1-18.

12. Klinge, M., Stenalderens Affaldsdynger. Hvilke Forhold typer paa, at de store Lerkar er blevet anvendt til Saltkogning? Naturens verden, 1934. 18(2): p. 60-70.

13. Mathiassen, T., Blubber lamps in the Ertebølle culture? Acta Archaeologica, 1935. 6: p. 139-152. 
14. Andersen, S.H. and C. Malmros, Madskorpe på Ertebøllekar fra Tybrind Vig. Aarbøger for Nordisk Oldkyndighed og Historie, 1984: p. 78-95.

15. Håland, R., Ethnographical observations of pottery-making in Darfur, Western Sudan, with some reflections on archaeological interpretations, in New directions in Scandanavian archaeology, studies in Scandanavian prehistory and early history, K. Kristiansen and C. Paludan-Müller, Editors. 1979: Copenhagen. P. $48-61$.

16. Fischer, A. and J. Heinemeier, Freshwater Reservoir Effect in 14C Dates of Food Residue on Pottery. Radiocarbon, 2003. 45(3): p. 449-466.

17. Kriiska, A., M. Lavento, and J. Peets, New AMS dates of the Neolithic and Bronze Age ceramics in Estonia: Preliminary results and interpretations. Estonian Journal of Archaeology, 2005. 9(1): p. 3-31.
18. Nakamura, T., et al., Radiocarbon dating of charred residues on the earliest pottery in Japan. Radiocarbon, 2001. 43(2B): p. 1129-1138.

19. Glykou, A., Pointed-based pottery: An experimental approach to the manufacturing of the pottery of the Late Mesolithic in Northern Germany. The Old Potter's Almanack, 2012. 17(1): p. 10-15.

20. Glykou, K., Neustadt - ein submariner Fundplatz des späten Mesolithikums und frühesten Neolithikums in Schleswig-Holstein. Untersuchungen zur Subsistenzstrategie der letzten Jäger, Sammler und Fischer an der norddeutschen Ostseeküste, 2011, Universität Kiel.

21. Koch Nielsen, E., Ertebølle and funnel beaker pots as tools : on traces of production techniques and use. Acta archaeologica, 1986. Vol. 57 (1986): p. 107-120.

\section{FIGURE CAPTIONS}

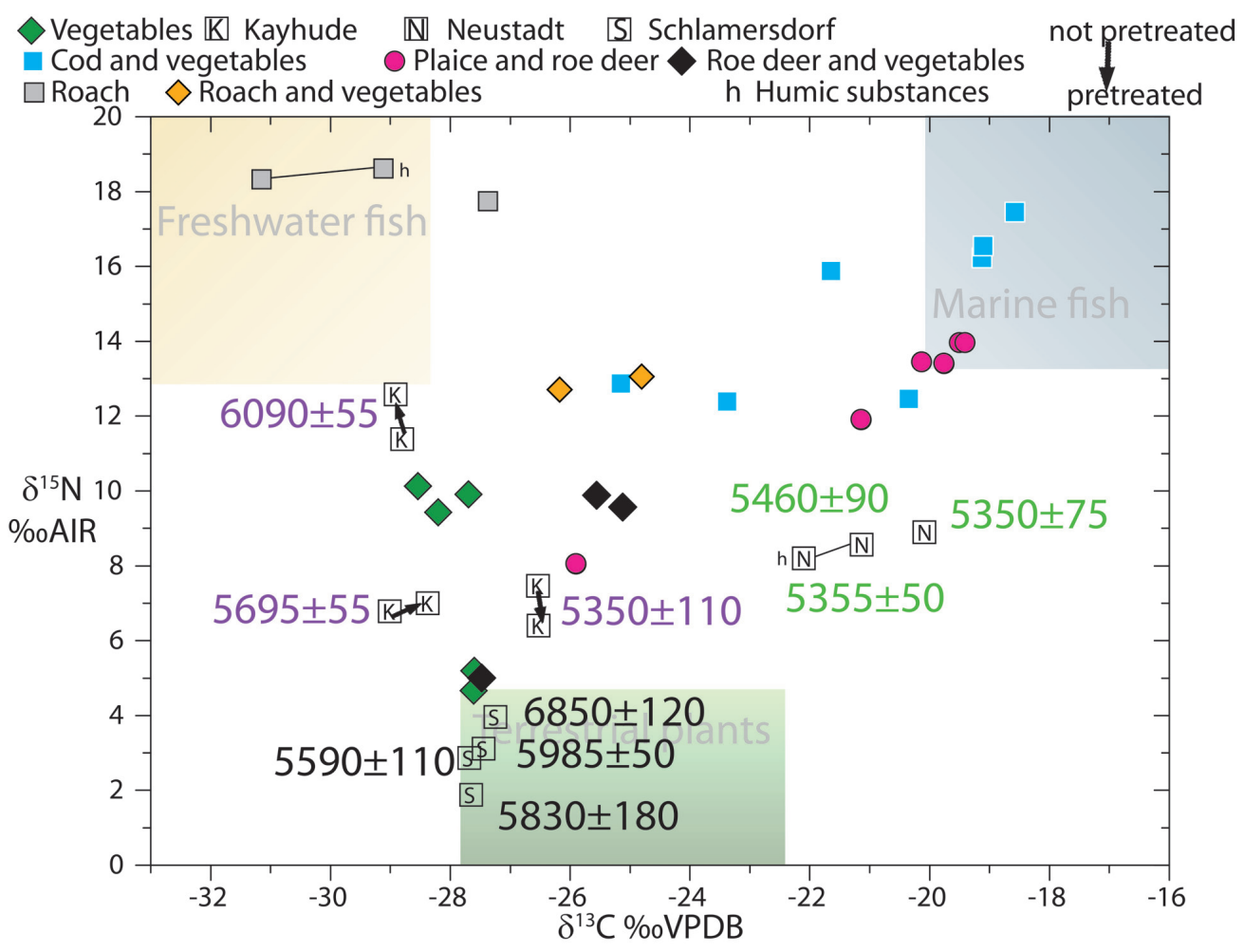

Figure 1 - The figure displays the isotopic values of a large range of experimental food crusts (coloured symbols). The same symbol shape and colour indicates samples from the same vessel. From three Ertebølle sites, the inland sites Kayhude (K) and Schlamersdorf (S), and the coastal site Neustadt $(\mathrm{N})$, stable isotopes were measured on food crusts, which were radiocarbon dated as well. Their radiocarbon age is written next to the symbol. After Philippsen [6]. 


\title{
EXPERIMENTAL STUDIES ON ERTEBØLLE POTTERY: FOOD PREPARATION AND RADIOCARBON DATING
}

(C) 2015

\author{
Bente Philippsen, Ph.D. \\ Aarhus AMS Centre, Department of Physics and Astronomy, Aarhus University
}

Abstract. This article summarizes my experimental and archaeological research about the earliest pottery in Northern Germany and Denmark, belonging to the Ertebølle culture, a Late Mesolithic hunter-gatherer-fisher culture. I will present firing and cooking experiments with copies of Ertebølle pottery and how a reference collection of experimental food crusts can be used to understand issues of radiocarbon reservoir effects and stable isotope measurements in food crusts. It will be shown that cooking food resources with a reservoir age, such as marine or freshwater fish, leads to the same reservoir age in the pottery. The results from the experiments will be compared to the archaeological record. I will discuss the implications of the experimental studies for radiocarbon dating of archaeological pottery, and for studies of style and function of ceramics.

Keywords: Radiocarbon dating, Mesolithic, pottery, Ertebølle culture, stable isotope analysis, food crusts

\section{УДК 902 \\ СОЧЕТАНИЕ РАЗНЫХ ПРИЕМОВ ЛЕПКИ СОСУДОВ ПО АРХЕОЛОГИЧЕСКИМ, ЭКСПЕРИМЕНТАЛЬНО-ТРАСОЛОГИЧЕСКИМ И ЭТНОГРАФИЧЕСКИМ ДАННЫМ (C)2015}

\author{
Г.Н.Поплевко, кандидат исторических наук, старший научный сотрудник \\ ИИМК РАН, Санкт-Петербург (Россия)
}

\begin{abstract}
Аннотащия. Изучение технологических приемов изготовления керамики рассматривается на примере материалов майкопской культуры на Северном Кавказе и данных этнографии. В качестве примера приводится экспериментальное моделирование круглодонных сосудов майкопской культуры, сделанных с помощью нескольких приемов. Трасологическое исследование структуры теста фрагментов керамики в изломе, показало, что можно определить зоны стыков лент. Внешняя и внутренняя поверхности керамики хорошо залощены, но можно определить ручную лепку по тонким линиям разнонаправленного лощения. Ручную лепку также можно определить и по некоторым фрагментам керамики на ее внутренней поверхности, сохранившей следы лепки лентами и разглаживания поверхности стыков руками. Часть фрагментов имеют очень плотную однородную структуру, которая формируется в результате использования приема выколотки, с использованием деревянной лопаточки или проковки стенок сосудов с помощью каменных орудий с обеих сторон. Часть техники изготовления сосудов удалось смоделировать с помощью экспериментов. Исследование данных этнографии по технике изготовления круглодонных сосудов показало, что методов моделирования таких сосудов намного больше. В работе представлены археологические, экспериментальные и этнографические данные по изготовлению как плоскодонных, так и круглодонных сосудов с использованием техники ручной лепки, выколотки и ковки (проковки стенок каменными орудиями с обеих сторон). В последнее время с помощью техники выколотки была выполнена серия экспериментов по моделированию круглодонных сосудов. Трасологическое исследование технологии изготовления круглодонных сосудов с помощью двух приемов выколотки, ранее не рассматривались.

Ключевые слова: археология; комплексное исследование керамики; этнографические исследования лепки керамики; трасологический анализ керамики; экспериментальное моделирование; ручная лепка керамики; техника изготовление круглодонных сосудов.
\end{abstract}

Комплексное исследование древней керамики состоит в использовании данных нескольких методов исследования к изучению керамики одного памятника. Современный подход к исследованию должен опираться на итоги анализа, полученного не только с помощью типологического и морфологического изучения керамики, но и на данные трасологического, технологического, петрографического, геохимического, экспериментального и статистического методов
[1-30].

Каждый из выше перечисленных методов дает новую, дополнительную информацию как о технике лепки сосудов, так и о технологии приготовления глиняной массы, структуре глиняного теста, характере примесей и технике обработки внутренней и внешней поверхностей, свойствах глин и отощителей. Помимо данных всех указанных методов, необходимо привлекать данные этнографии, которые помогают лучше 